\title{
Poverty Reduction Strategies for Smallholder and Family Farmers: Models and Lessons
}

\author{
Amira E. Mahmoud 1
}

\begin{abstract}
For many years in developing countries in Asia, Africa and Latin America, there has been much effort to alleviate poverty and improve the standard of living for the poor. However, most of improvements are happening in urban cities while the majority of the poor are located in rural areas. This paper examines common poverty reduction strategies for smallholder and family farmers in developing countries from field work cases in North, East and West Africa.

The strategies reviewed include; commercial projects, building infrastructure, subsidize farm inputs and supporting subsistence farming.

Keywords: Commercial projects; Development; Subsidy; Subsistence; entrepreneurism; Family Farms; Emerging farmers.

\section{INTRODUCTION}

The world's poverty indexes revealed that two thirds of the poor live in rural areas and their main activity is farming, prevalent smallholder and family farmers (Todaro and Smith, 2015). Enhancing the potential of smallholder and family farms recognized as critical in alleviating poverty and producing food for the world; they produce 80 percent of the world's food production. Smallholder and family farms represent up to 500 million farms and occupy 70-80 percent of farmland. At the same time, they act as catalyst for local economy and they are the main source for labor worldwide (FAO, 2015a; FAO; 2015b). Nevertheless, smallholder and family farmers are often prone for food insecurity and they face great deal of challenges. These include: limited access to knowledge and innovation; lack of farming inputs and extension services; expose to climatic shocks and prices instability; exclusive from decision making and international policy (FAO, 2016). Consequently, these constraints generate burden not only on smallholder farmers but also on facing the growing demand on food to feed future generation. This paper evaluate commonly used strategies to alleviate poverty among small farmers and family farmers in developing countries in order toidentify the ones that can be implemented more effectively to achieve the ultimate goal of poverty alleviation.
\end{abstract}

\footnotetext{
${ }^{1}$ School of Humanities and Social Sciences, Newcastle University Received Novmber 29,2017, Accepted December 31, 2017
}

\section{MATERIALS AND METHODS}

The author has gathered data for this study from different sources. Some data came from field notes taking through implementing extensive developmental projects in Egypt with different NGOs in the period 2011 to 2013. In addition, some interviews were conducted from agricultural officers from East and West Africa coming to Australia for post graduate education. These case studies set practical examples to consider for Rural Advisory Services (RAS) when applying poverty reduction approaches. The contention of this paper is to address common strategies that work well and other may not work in supporting smallholder farmers.

\section{A-Commercial Agriculture Projects}

This type of projects is designed to enable smallholder farmers to maximize the use of land resource that they already own to generate or increase their income. Commercial projects guide smallholder farmers to become market driven producers. These projects attempt to deal with increase food security for smallholder famers through increasing their cash income. This type of project is implemented through government support or Non-Government Organizations (NGOs).

In developing countries, when smallholder farmers shift to commercial agriculture they face several challenges such as cost of transportation, risks involved in competitivelarge market and lack of business skills. The need to go beyond subsistence farming was first introduced by Neo-liberalism. Followed this conceptual change, there was a shift in community development approaches from welfare to commercialization. Most donor organizations assumed and advocated that entrepreneurism is the best way to alleviate poverty (Harper and Tanburn, 2005; SIDA, 2003). The expectation was that if the poor could earn more money they would not be hungry anymore. Therefore, many governments in developing counties adopted this approach because of international pressure from the World Bank, international NGOs and other donor agencies. Ideally, once the commercial projects got established farmers expectedto sustain themselves and reinvest their profit. In ideal cases, commercialization could no doubt help the small farmers to profit and improve their life in general. In reality, smallholder 
farmers have been struggling with the practicalities of commercial agriculture for the following reasons:

i.A typical market in a rural area is limited by the number of residents who are living in the same area. This limitation prevents the farmers from earning enough profit from market to support their household needs. In addition, high competition in similar produce.

ii.Some ambitious small farmers who wish to market their produce in a city market got hindered by poor road system connected to bigger markets.

iii. The lack of information around the market and the absence of insurance for farmers entering the market cause a fear of taking risks and falling into food insecurity (Todaro and Smith, 2015).

iv. The majority of the agricultural extension programs neglect smallholder producers while strongly supporting commercial farmers (Leahy, 2011). As a result, Smallholder farmers lack the marketing skills and most of development agencies do not provide training for farmers beforeshiftingto commercial production.

v.In some developing countries, small farmers often lack the necessary education to manage a small commercial project work. For instance, small farmers in Sub-Saharan Africa lack mathematical skills which limit their marketing skills. Those farmers and their parents once were labor in large commercial farm as manual laborers. Their experience of farming is farming for subsistence. The farm goods that people buy (including poor people) are produced on large commercial farms owned by white people. These white owners are well educated and handle math. However in Bali, every poor farmer in North Bali is used to produce for the market and knows the math well.

vi. It does not make economic sense to be producing for the market if small farmer have a very small holding (less than 2 ha of cropping land and access to less than 4 hectares - per household - to grow wood for fuel). This is because of the gap between the farm gate price of commercial cash crops and the retail price of basic food. Even if a farmerownlarger pieces of land, the most sensible thing is to designate those 2 hectares for household food consumption and use the remaining land to produce a surplus for market.

vii.In order for small farmers to benefit from commercialization they are required to specialize. This is a significant challenge for small farmers in developing countries because of land fragmentation. In Latin America for example, the major problem for farmers with agrarian land is the concentration of ownership. In Asia the problem is exacerbated due to overpopulation (Todaro and Smith, 2015). As a result, some argue that many small farmers cannot make use of simple machinery for farming which usually result in low yields. In fact, this is not a problem in societies where the unemployment ratio is high with plenty of labor. But the actual problem is the primitive farm practices. The land situation in Sub-Saharan countries is different because famers have access to cropping land and average ownership is higher than Asian countries. However, most of the African farmers usually have limited access to agricultural inputs and rainfall is low. In this case, it would be very beneficial for farmers if governments and NGOs would provide subsidized agricultural inputs. Also, they could assist farmers to build water tanks to harvest rainfall or dig water wells. In addition, governments should combine individual marketing into co-operative marketing to support small farmers.

\section{A1. Commercial Group Projects}

It is very common for many governments and funding agencies to group smallholder farmers together to workin a commercial project and set up a "cooperative" for marketing purpose. These projects are preferred for several reasons. It serves many participants and share benefits for expensive start up equipment. When smallholder farmers are combinedtogether in a cooperative, they can contribute to a common purpose and mirror the large holdings that are usually used by commercial farmers. A final reason is that group projects 'look better' in terms of proving the success of the project. It is easier to follow up group projects, rather than having to tour individual smallholder farms. At the same time, as we will see, such group commercial projects have considerable challenges.

\section{Case 1 Rural Enhancement Projects in Malawi}

Raising goats for profit was one of the rural enhancement projects implemented in Southern Malawi. The government funded this project and selected 15-20 village members to provide withinput materials such as; goats, feeding and building materials to make goat sheds or corrals to protect goats. The project went well during the initial period while participants received funding and support. However, shortly after the funding stopped and the project's responsibility was shifted to the beneficiaries, the project collapsed. The reason behind its failure was villagers lacked management skill and the project itself did not generate enough money for its beneficiaries. An extension officer from Malawi reported the following: 
We tend to push our own ideas what we want when we go to the village. We also pretend as if we do what people needs but when we start the project we find people are not fully into the project.

This is a typical problem with top down approach. Most of project officers visit villages and convince farmers with new innovations. The project provides farmers with free inputs, training, infrastructure etc. In fact, most of villagers do not trust the extension officers and only joined for these incentives. A better approach would be to have a pilot study, where the project officer has a chance to speak with prospective farmers. Together theyaddress farmers' needs and project's capacity.

A third reason is group dynamics that are often challenging especially with large groups. In this example, the main problem was half of the group fed the goats while the rest did not. However, both groups expected to share profit equally. The group which fed the goats became angry with the other group and in the end no one fed the goats. This showed how badly poor people cooperate in commercial cooperatives.

In comment on this classic failure situation:

-The infrastructure should have been used for a broader benefit for all community members'not selective groups. The fund could have been used to build a fence around the grazing land in the village which could benefit the whole village.

-The result of this project is a predictable ending for most government sponsored agribusiness projects. It would work better if the project followed the tradition in this area of Malawi where farmers take individual ownership and raise animals in their houses. Usually in group projects, it is hard to track the participants who fail in their responsibility in the project. However, when they take individual responsibility they keep the project going for a longer time because the individuals gain direct benefits.

After almost three years of implementing commercial group projects in rural villages in Egypt,

I can safely say this was an unsustainable and inefficient way of addressing food security. It was a classic ending for group projects to fail only few months after its start. Once, in a conversation with an NGO's chairman I explained that we might need to change our commercial group approach. His answer was 'We cannot stop commercial projects; our donors love to see these type of projects because they are more convincing. Therefore, they continue to donate and we continue to work'.

\section{Case 2 Mushroom Production Project in Malawi}

A mushroom production project was initiated in Malawi for smallholder farmers for commercial production. The project officer however discovered that in order for beneficiaries to be able to transact business with big companies that would purchase their produce; they needed training in agribusiness and basic numeracy skills. After a long period of training, the participants did not cope. Many issues challenged this project:

-The participants lacked the minimum numeracy skills which were required to run a business and deal with marketing effectively.

-Most of the farmers were accustomed to subsistence farming practices. They produce what was enough for their households and they swapped or gave mushrooms to their neighbors. A project like this would have been more successful to start by supporting the subsistence model which fits perfectly into the existing culture. Eventually the project could shift to commercial production.

In both commercial and subsistence group projects, it is important to provide participants with proper training prior to the project start. The training can be offered by the government or NGOs and can also be offered for group and individual projects. However, the commercial group projects often receive higher priority.

\section{A2. Individual Projects}

Individual projects showed success in comparison to group projects. Because individual projects had no group dynamics issues. It was easier to identify and correct mistakes when things went wrong. Individual projects also showed much success in the African culture where people were not accustomed to work in self-managed groups. There are different types of individual projects, although Inclusive Family Project and Emerging Farmer Project are the main focus here.

\section{A2.1. Inclusive Family Projects}

Inclusive family projects offered to any family in a community who shows interest and commitment. The advantage of these projects is to reduce community jealousy, theft of infrastructure and ambivalence about the project (Leahy, 2009). In addition, reducing the cost of material and infrastructure allows maximum benefits for greater number. Also, inclusive family projects reach the right candidateswho truly want to join the project unlike other projects with free inputs that create fake interests. The following is an example for this type of project from Malawi.

\section{Case 3 Goats Offspring Project in Malawi}

This project was carried out under the rural development strategy in the central region of Malawi. 
The project offered help for individual beneficiaries to enhance a livestock particularly pigs and goats. Participants required showingcommitment by building their own corrals for animals by using local materials. It was then agreed that each six months the beneficiaries keep offspring and pass on goats to another group. Ideally if the project started with 5 beneficiaries, by the end of the year there would be double that number. Each member was responsible for keeping the goat in their house and the rest of the group were responsible for supervising to keep them safe for next beneficiary. The project was very successful and after 5 years all the village members received goats. So, it was decided to duplicate this project and pass it on toanother village. This project was successful because of the following factors:

-The project fitted people's interest and experience in raising goats in central Malawi.

-The project was offered to individuals and had no group dynamics issues or fights over money.

-The project did not require the recycling of profit to keep it running. In fact the participants saved in feeding cost by sending goats grazed freely on the community grazing land.

-There was group pressure because the beneficiary was supervised by other members and they acted like community police.

-There was commitment from the beneficiaries from the outset as they had to first build their own corral.

\section{A2.2. Emerging Farmer Projects}

In most cases emerging farmer projects are given to middle class farmers who own more land and they often have another job besides farming. The project chooses slightly wealthier farmers to start a small enterprise using their own smallholding as the basic capital. In addition, the project supplies education on a particular technology and all necessary inputs to start (Leahy, 2011; Leahy and Goforth; 2012). Because these were expensive, such projects cannot be offered to all poor people in a given area, but only to a few selected families. The key idea behind the leading farm models is that the chosen farmer would sell their products and earn money to keep funding the inputs necessary to continue this commercial technology. The project's success depended on farmers having the business skills necessary to run a commercial project and save money to pay for the next round of inputs. The following project was a leading farmer model from Uganda (Leahy, 2011).

\section{Case 4 leading farmer Model- Potatoes Uganda}

The project was sponsored by the National Advisory Agricultural Servicein Uganda. Basically, farmers with large holdings were chosen to receive inputs worth 2 million shillings; potato seeds, fertilizers and herbicides. Each participant was expected to establish a potato garden that would serve two purposes; a leading unit to provide training for other potato farmers and distributing center for improved potato seeds.

There were some concerns with this model project as it encouraged dependency amongst the participants. For example, most farmers would wait for improved seeds from the extension center rather than improve their own. Also, these projects targeted the middle class farmers so the benefits of these projects did not go to the poor farmers who needed the most. Furthermore, the leading farmer projects are meant to provide training to other farmers who can learn from a successful model. However, in many cases the leading farmers do not transfer the knowledge to others, consequently defeating the purpose of the model.

\section{B. Building Infrastructures}

Facilities and infrastructure has always been neglected and left behind. They lack communication and educational services, proper roads, sanitation, health and irrigation systems (Dorward et al, 2004; Thapa, 2009). In this strategy the poor will not derive direct benefits for food security. Instead, projects like this will help smallholder farmers to substantially improve their output and reduce their expenses for transportation (Leahy, 2009; MIVARF, 2009). A case study by the International Fund for Agricultural Development (IFAD) in Tanzania showed the benefits of building roads and assisting markets. It created incentives for smallholder farmers to increase their production. It also improved and expanded the local market by increasing trade between different villages. Furthermore, it gave local farmers the opportunity to buy farm inputs (MIVARF, 2014). These benefits were very useful for small farmers who had minimal financial ability, although it does not help the poor who lack the financial means to buy food regardless of its availability. In addition, building roads and assisting markets brought about better market information. Consequently, it removed the location advantage enjoyed by unscrupulous marketing. Another great advantage was these programs provided work while the construction was being put in place.

\section{Free or Subsidized Farm Inputs}

A subsidy is defined as reduction in the sale price of an item in order to enable the public to obtain it at a cheaper price than normal. The difference between the price at a producer's side and what a consumer eventually pays is the amount of subsidy which is often paid by governments through public resources (Takeshima and Lee, 2012). There are benefits in a 
subsidy for agricultural inputs. Subsidy is an important strategy to support the poor and enable smallholder farmers to obtain access to farm inputs at a cheaper price. This helps them to continue farming and bridge the gap between low market prices for produce and high cost of agricultural inputs. Subsidies help small farmers to increase their income as well as contributing to food security within a household and expand the local markets (Leahy, 2009). In addition, there are cases where a free or subsidized approach is the only way to save the poor as showed in following examples from Liberia, Malawi and Myanmar (formerly Burma).

\section{Case 5 Capacity building for Rice Farmers in post war Liberia}

This was one of the post war projects to help smallholder farmers to build seed banks in Liberia and Sierra Leone. Due to war, most of farmers could not plant rice and so they even ate their seeds. The project was funded by the International Fund for Agricultural Development (IFAD) to help farmers to increase their rice productivity, and to foster agricultural development by giving inputs such as seeds and fertilizers. Eventually, it was meant that would lead farmers having surplus beyond their subsistence to market. The project was successful to some extent but had some challenges. An extension officer (Mr. D.) from this area explained problems with the project:

IFAD allocated local NGOs to provide seeds and interventions for farmers. But the seeds arrived late for transplanting and some of the seeds were expired. In addition, farmers did not find good technical support for dry season.

(Interview, 2015)

\section{Case 6 Soft Loans for Small Farmers/ Agribusiness groups}

One of the most common projects in Malawi involved giving farmers assistance with farm inputs to improve their production. Small farmers received soft loans in form of seeds, fertilizers and pesticides. The farmers were expected to repay back when a season was over and produce was sold. This type of project did not succeed in Malawi because the farmers who took loans never paid them back. One of the project officers said:

This project failed because farmers once they saw external help they expected support and they relied on it and they never repay it. However, every time they asked for more even after the project had been dismantled.

A project of this nature should be given selectively to farmers who show commitment, proven track record of credit worthiness .It should not be offered to all farmers. Beneficiaries can also be made to bring reliable guarantors who will be held responsible when beneficiaries fail to meet their obligations.

\section{Supporting Subsistence Agriculture}

The contradictory approach to Neo-liberal strategies and promotion of commercial agriculture is supporting subsistence farming. This is in fact the cheapest way to achieve food security for small farmers with limited holdings. The food grown by subsistence farmers on one hectare will cost more to buy in market so, it makes economic sense for smallholder farmers to grow their own food. The agrarian system in many developing countries and especially in the African context has supported subsistence farming long before the Green Revolution and the emergence of market liberalization. The main exceptions to the prevalence of subsistence farming in Africa are to be found in some colonized areas where farmers grow cash crops for export such as legumes in Tanzania, cut flowers in Kenya and Ethiopia, green beans in Niger, sugar, cocoa and coffee in Kenya (Todaro and Smith, 2010). The majority of farmers used to grow food for their own family consumption and surplus could be saved for off season needs, exchanged with neighbors or sold for extra cash income. This system worked perfectly well and proved to be one of the best approaches in securing food for rural residents. However, the constant growth of big cities and urban society resulted in high demand for food which led governments to shift many farmers to commercial production in order to meet the rising market demands. Also, the Neo-liberals promoted the idea that commercial agriculture was the only real form of agriculture for economic growth and development. This vision came from white farmers in Africa who were seen to represent the highest stage of agricultural development and the small black entrepreneurs followed same steps. Moreover, Neo-liberal promoted that most of Africa's economic problems come from lack of entrepreneurship in all fields including agriculture (Leahy, 2011). Inreality most of the economic problems were escalated because of Neoliberalism ideas. Because of the commercialization drive, many subsistence farmers switched to cash crops hoping to make a better income and achieve food security. Nevertheless, stallholder farmers suffered greatly from the unpredictability of global market prices. For example coffee prices fell from $\$ 2,300 /$ tonne in 1995 to $\$ 800 /$ tonne in 1999 (Leahy, Food Security Lecture, 2014). As a result, the poor did not fit into commercial farming and lost their traditional forms of livelihood (Nayak, 2009).

In developing countries, the current low performance of subsistence farming cannot be understood without looking at its history. In a nomadic 
stage, there used to be plenty of agricultural land and each familyhad access to the land which was farmed extensively. Once the land was exhausted and lost its productivity a family would move to a different land (Todaro and Smith, 2010). This shifting cultivation land system has become impossible to sustain due to over population and the high demand on agricultural land. As a result, most of the subsistence farmers who had practiced nomadic systemin the past ended up by getting low returns because they lacked knowledge to maintain a good crop and did not receive extension support. Nevertheless, there are still many reasons that subsistence production should be supported:

-Subsistence farming is the most direct way to secure food for smallholder farmers within each household that result in mitigating food insecurity regardless of market prices (Leahy, 2009).

-Subsistence farming is an easy and affordable replacement for commercial agriculture. The current state of commercial agriculture in developing countries often fails especially in poor rural areas where farm inputs are expensive. Farmers usually buy farm inputs on loans and when they sell their produce they ought to repay most of theirprofit in order to continue producing in the subsequent seasons. However, poor farmers have other commitments for their families and they end up investing less money in the farm. As a result, they become more and more indebted which negatively affects their food security situation.

-Subsistence farming can be improved with Permaculture techniques. These methods provide farmers with many benefits including affordable methods for disease control, pest and weed management. Also subsistence farmers enjoy a wide range of activities within their work compared to commercial agriculture where they become disconnected from the whole production process. Permaculture provides a variety of nutritional inputs for the household. It also minimizes the risk of dependence on one crop.

-Because subsistence farmers do not generate any cash income from their farming, they have to use organic methods and mostly eco-friendly practices. For example subsistence farmers use compost and manure, nitrogen from legumes, and provide water using contour bunds. Commercial agriculture however, consumes massive quantities of cheap oil as well as huge amounts of pesticides and fertilizers. Current commercial agriculture practices exacerbate environmental damage and the loss of natural habitats and reduce biodiversity.
-Subsistence strategies fit the needs of the poor, especially in rural areas in developing countries. The reason is rural areas are commonly characterized by large numbers of family members, high rates of unemployment and very low income or none at all. Therefore, it is wiser for such families to grow their own food and engage all their family members in productive employment.

-Finally, subsistence strategies are the best for food security as they also build self-esteem and independence for the poor when they succeed in securing food for their families (Leahy, Food Security lecture, 2014). Below is a feedback from a TSURO NGO's beneficiary from Chimanimani Zimbabwe who was trained insubsistence agricultural production:

Before then I lacked some certain skills and knowledge on how to farm. But through TSURO I had to attend workshops and I would implement those skills that I was trained on. I have also improved in my yield from the farm. I am now getting enough to feed my family, and surplus to sell.

(Leahy, Food Security Lecture, 2014)

\section{Case 7 Compost Making for Home/Roof garden in Egypt}

One common wasteful practice in rural areas in Egypt is burning wheat or rice straw. Also, most rural women do not compost their kitchen scraps, it goes to feed chickens or rabbits if they have any. A series of workshops was held in two villages to teach householders how to compost kitchen scraps and use some of their animal manure (chickens, rabbits and pigeons). At the beginning the intervention failed because it was form of lectures only then later on was shifted to demonstration approach.

The demonstration approach was very successful; the project officer chose a local leader as a leading unit.The project aimed to change behavior of householders and small farmers. There was a weekly meeting to check on the composting progress at different stages. By the time the first compost was ready for use; a few members had already started making their own compost at home. Also, many small farmers came to attend the second round of the compost making workshop. It was important to demonstrate to participants that it did not involve much work or dedication and it was important to see the time involved and how to balance the wet with the dry matter.

Another activity under these workshops was a demonstration of the proper use for animal manure. Some families raised rabbits for subsistence but they had problems with manure odor. The rabbits'feces were 
dried and stored for farm uses or in roof garden. This practice worked very well with the Egyptian hot dry weather especially in summer. It is very important to mention here that a project officer had a model unit to raise rabbits for meat. It was originally for profit to fund other projects in the village. The farmers heard about this unit and visited. This unit later became a training unit for farmers and rural women who raised rabbits.

\section{Case 8 Land Resource Conservation in Malawi}

Land conservation projects in Malawi were intended to look after agriculture and forests. The project focused on land resource conservation through two areas: soil fertility improvement and water conservation. Soil conservation was achieved through physical and biological methods.Participants were taught various skills included constructing check dams, making terraces, realigning the ridges so that they follow the contour. An "A" frame was used to design ridges so that they would follow the contour of land. In addition, farmers were taught to dig swales to conserve water. In the biological method, farmers were supplied with grass seeds such as Vetiver grass to plant along a swale.

These interventions made progress but farmers showed some resisted adopting for future. Most of farmers sawthose conservation methods exhausting and energy sapping. Although farmersbelieve in the value of these practices for healthy soil, they were discouraged for the amount of hard work that involved. For example, the Vetiver grass required trimming at least once a year but they would not trim it and it die.

The soil fertility issue was mostly addressed by encouraging farmers to make compost and form groups to work together planting seedlings or exchanging seeds to make use of forestry land. One of the major challenges was that farmers lacked the ability to look after companion planting. For example, if farmers planted maize and tree seedlings, they took care of maize only. Another method for soil conservation was to make compost. However, some farmers did not own livestock so it was difficult to make manure. They also compared their production with the compost to those who used industrial fertilizers. In most cases they could have a better production using compost if they applied the right amount but they would not.

\section{CONCLUSION}

Although smallholder and family farmers produce 80 percent of the world's food supply, occupy 70-80 percent of farmland and represent over 500 million farms, the majority of them are poor and highly vulnerable to food insecurity. This is due to several reasons; the poor adopt primitive or traditional farming techniques, over cropping and limited land tenure to expand their production. In addition, subsistence farmers receive limited agricultural extension support compared with commercial farmers whose impact is clearly reflected in any economy. One can safely say there are many options which can be used to mitigate poverty for smallholder farmers. However, the biggest challenge for RAS is to determine which strategies should be used to support smallholder farmers; commercial projects, building infrastructure, subsidize inputs and supporting subsistence farming.

Supporting subsistence projects is by all means the best approach to alleviate poverty and sustain food security within the household by far. Despite the great advantages of subsistence projects whether group or individual, they are less recognized by government extension programs or donor agencies. The second best option for smallholder farmers will be free/subsidized farm inputs. But it should be limited to the neediest. On the other hand, commercial project might look attractive and promising but in fact this type of projects are challenging for smallholder farmers to adopt. Small farmers' inclusive family projects and emerging farmers' projects are the most successful commercial projects while group commercial projects fail the most.

\section{REFERENCES}

Dorward, A., P. Wobst, H. Lofgren, H. Tchale and J. Morrison 2004. Modelling Pro-Poor Agricultural Growth Strategies in Malawi: Lessons for Policy and Analysis', Wye, Ashford, UK, Centre for Development and Poverty Reduction, Department of Agricultural Sciences, Imperial College London.

FAO. 2015a. Enhancing the Potential of Family Farming for Poverty Reduction and Food Security through GenderSensitive Rural Advisory Services. http://www.fao.org/3/a-i5120e.pdf

FAO. 2015b. The State of Food Insecurity in the World. http://www.fao.org/3/a-i4646e.pdf

FAO. 2016. Tailoring Rural Advisory Services for Family Farms. http://www.fao.org/3/a-i5704e.pdf

Harper, M. and Tanburn, J. 2005. Mapping the Shift in Business Development Services: Making Markets Work for the Poor. UK: ITDG Publishing, pp. 1-8.

Krahe, D. 2009. 'a New Approach to Aid: How a Basic Income Program Saved a Namibian Village' available online: ihttp://www.spiegel.de/international/world/a-new1 approach-to-aid-how-a-basic-income-program-saved-at ınamibian-village-a-642310.html

Leahy, T. and Goforth.M. 2012. AWining Formula. www.gifteconomy.org.au/page 177.html

Leahy, T. 2009. Permaculture Strategy for the South African Village' Palmwoods, QLD: Complete Printing Services, pp. 47-55; 181-183; 209-212.'Www. gifteconomy.org.au 
Leahy, T. 2011. Food Security Projects for Africa: a Case Study from Uganda, www.gifteconomy.org.au/page108.html

Leahy, T. 2014. Lectures in Rural Food Security and Sustainable Agriculture for Community Development'.

Market Infrastructure, Value addition and Rural Finance (MIVARF). 2014. Environmental and Social Management Plan Summary. IFAD pp.1-18.

Nayak, N. 2009 Development for Some is Violence for Others: India's Fisherfolk', In Ariel Salleh (ed), EcoSufficiency and Global Justice, Pluto Press, London, pp. 109-120.

Swedish international development cooperation agency (SIDA) 2003. Making Markets Work for the Poor:
Framework for SIDA's Support to Private Sector Development', Sweden: EditaSverige AB, 2003, pp.7-90.

Takeshima. H., \&Lee.H. 2012. 'Mozambique strategy support program agricultural inputs subsidy and their developmental International Food Policy Research Institute.

Ifpri-copyright@cgiar.org

Thapa, G. 2009. Smallholder Farming in Transforming Economies of Asia and the Pacific: Challenges and Opportunities' Discussion Paper prepared for the side event organized during the Thirty-third session of IFAD's Governing Council.

Todaro, M.P. and Smith S.C. 2015. Economic Development' Harlow: England. Pearson Education Limited, Twelfth Edition, pp.416-447.

\section{الملخص العربي}

\section{دراسة لبعض نماذج سياسات مكافحة الفقر لصغار المزاعين فى مصر وبعض الاول الافريقية}

$$
\text { اميرة السيد عبد الله محمود }
$$

$$
\begin{aligned}
& \text { منذو سنو ات عديدة في البلدان النامية مثل آسيا و أفريقيا من حالات عمل ميداني فى عده بلدان تقع فى شمال وشرق } \\
& \text { و أمريكا اللاتينية، بذلت جهود كبيرة لتخفيف وطـأة الفقـر } \\
& \text { وتشمل الاستراتيجيات التي جرى استعر اضها؛ مشاريع } \\
& \text { رياده الاعمال الزراعية، بناء و تطوير البنية التحتية، ودعم } \\
& \text { المدخلات الزر اعية، ودعم زر اعة الكفاف. } \\
& \text { الكلمات الافتتاحية: مشاريع ريادة الاعمال الزر اعيــة، } \\
& \text { دعم المدخلات الزر اعية، دعم زر اعة الكفاف }
\end{aligned}
$$

